Araştırma Makalesi • Research Article

\title{
Çanakkale İli Dalış Turizmi Potansiyelinin İncelenmesi
}

\section{An Investigation of the Diving Tourism Potential of Çanakkale Province}

\author{
Şefik Okan Mercan ${ }^{\mathrm{a},}{ }^{*}$, Ayşe Sünnetçioğlu ${ }^{\mathrm{b}}$, Ezgi Can Uşak ${ }^{\mathrm{c}}$ \\ a Doç. Dr., Çanakkale Onsekiz Mart Üniversitesi, Turizm Fakültesi, 17000, Çanakkale/Türkiye. \\ ORCID: 0000-0003-1737-014X \\ ${ }^{\text {b }}$ Dr. Öğr. Üyesi Çanakkale Onsekiz Mart Üniversitesi, Gelibolu Piri Reis Meslek Yüksekokulu, 17000, Çanakkale/Türkiye. \\ ORCID: 0000-0002-4295-9776
}

${ }^{c}$ Yüksek lisans öğrencisi, Çanakkale Onsekiz Mart Üniversitesi, Lisansüstü Eğitim Enstitüsü, 17000, Çanakkale/Türkiye. ORCID: /0000-0001-8533-869X

\section{MAKALE BİLGISİ}

\section{Makale Geçmişi:}

Başvuru tarihi: 28 Mayıs 2018

Düzeltme tarihi: 12 Temmuz 2018

Kabul tarihi: 06 Ağustos 2018

Anahtar Kelimeler:

Dalış turizmi

Alternatif turizm

Çanakkale

\section{ARTICLE INFO}

Article history:

Received May 28, 2018

Received in revised form July 12, 2018

Accepted August 06, 2018

\section{Keywords:}

Diving tourism

Alternative tourism

Çanakkale
ÖZ

Dalış turizmi, alternatif turizm türlerinden biri olup, Çanakkale'de de gerçekleştirilmektedir. Çalışma ile, Çanakkale'de dalış turizmi potansiyeli ortaya konulmaya çalıșılmıştır. Çanakkale'nin dalış turizmi potansiyelini değerlendirmek için katılımcılarla yapılandırılmış görüşmeler gerçekleştirilmiştir. Böylelikle, turizm paydaşları için sürdürülebilir dalış turizmi hakkında öneriler getirilmiş, Çanakkale dalış turizmine ilişkin güçlü ve zayıf yönler ile firsat ve tehditler ortaya konulmuștur. Çalıșmada, Çanakkale'nin dalıs turizmi potansiyelinin yüksek olduğu ancak birçok faktörün dalış turizminin gelişiminin önünde engeller oluşturduğu sonucuna ulaşılmıştır.

\section{Giriş}

Su altı dalışı aktivite olarak 1950 ve 1960 yıllarında batan gemilerin merak uyandırması sonucunda yapılmaya başlanmıştır. Su altı dalışı, oksijen tüpü regülatör gibi malzemeler yardımı ile suyun altında uzun süre kalabilmek olarak tanımlanmaktadır (Albayrak, 2013: 214). Bu aktivitenin turizme uyarlanmış hali ise dalış turizmi olarak ifade edilmektedir.

\footnotetext{
* Sorumlu yazar/Corresponding author. e-posta: okanmercan@comu.edu.tr
}

Su altı dalış turizmi macera turizmi çeşitlerinden biri olarak ele alınmaktadır (Akkoç, 2015: 1) nitelenebilir. Dalış, kıyı ülkelerinde oldukça önemli bir turistik aktivitedir. Bunun yanı sıra dalış turizmi pahalı bir aktivite olduğu için önemli ve ekonomik getirisi yüksek bir turizm çeşidi olarak ele alınmaktadır (Yarmacı vd., 2017: 67). Su altı dalış turizmi macera turizmi çeşitlerinden biri olarak ele alınmaktadır (Akkoç, 2015: 1). Son yıllarda, en çok talep edilen alternatif turizm çeşitlerinden birinin su altı dalış turizmi olduğu ve bazı destinasyonların ön plana çıktığı söylenebilir. 
Günümüzde dünya çapında en çok tercih edilen dalış destinasyonları olarak; Bahama Adaları, Beffin Adası, Misır Kızıldeniz, Maldiv Adaları sayılabilir (Erkurt ve Paker, 2014: 134; Yarmacı vd., 2017: 67). Bir senede yaklaşık 10 milyon Avrupalı turistin, dalış için Mısır-Kızıldeniz'e gittiği belirtilmektedir (Erkurt ve Paker, 2014: 134). Türkiye de ise tercih edilen dalış destinasyonları; Ayvalık (Balıkesir), Datça, Bodrum (Muğla), Kemer (Antalya) olarak belirtilmektedir (yigm.kulturturizm.gov.tr). Çanakkale de bu önemli destinasyonlar arasında yer almaktadır. Özellikle, Eceabat, Gökçeada ve Bozcaada'da bulunan antik kalıntılar ve su altı özellikleri Çanakkale'yi önemli bir dalış turizmi destinasyonu konumuna getirmektedir (Babazade, 2017: 28). Çanakkale'de dalış yapmaya müsait olan noktalar; Saros, Gökçeada ve Bozcaada olarak belirtilmektedir (yigm.kulturturizm.gov.tr). Çanakkale'de dalış turizmi ilk defa 1990'da bir dalış okuluyla başlamıştır. 2000'li yıllarda hızla gelişen dalış turizmi günümüzde ilin, Türkiye'nin önemli dalış bölgelerinden biri haline gelmesini sağlamıştır (Babazade, 2017: 28).

İlgili alanyazında çalışmalarda; destinasyonların dalış turizmi açısından potansiyelini ele alan çalışmalara rastlamak mümkündür. Scalkos vd. (2009) Yunan dalış endüstrisinin paydaşlarını belirleyerek Yunanistan'daki dalış turizminin mevcut ve gelecekteki potansiyelini belirlemek için bir araştırma yapmıştır. Benzer şekilde Babazade (2017) çalışmasında İzmir su altı dalış turizmine yönelik bir SWOT analizi yapmıştır. Resif alanları ve resif alanların güvenliği (Wilks ve Davis, 2000), dalış turizmi ile ilgili yapay resiflerin geliştirilmesi ile ilgili uygulamalar (Stolk vd., 2007) araştırılan konulardandır. Bir destinasyonun su altı kültürel mirasını değerlendiren çalışmalara da rastlamak mümkündür. Özalp'in (2004) Çanakkale'nin su altı kültürel mirasını oluşturan batıkları ele almıştır. Jeffery (2004), II. Dünya Savaşı su altı kültür mirasının dünya mirası listesine ilişkin bir dizi konuyu ele almıştır. Perez-Alvaro (2016) çalışmasında iklim değişikliğinin su altı kültürel mirası nasıl etkileyeceğini araştırmıştır. Staniforth vd. (2009) ise çalışmada; su altı kültürel miras hukukunu ele almıştır. Dalış deneyimi ele alınan bir diğer konudur. Lucrezi vd. (2013) ile Akkoç (2015) katılımcıları dalış deneyimi yaşamaya iten motivasyon faktörlerini incelemişlerdir. Naidoo vd., (2016) yaşanan deneyimden memnuniyeti araştırmıştır. KirkbrideSmith vd. (2013) çalışmasında Barbados'ta dalgıçların yapay resif algılarını incelemiştir. Dalış faaliyetlerinin doğal yaşam üzerindeki etkileri pek çok araştırmacının dikkatini çekmiştir (Prior vd., 1995; Hawkins vd., 2005; Hasler ve Ott, 2008; Benitez-Cabrera vd., 2011).

Çalışma ile; Çanakkale'de dalış turizmi potansiyelinin değerlendirilmesi ve dalış turizmiyle ilgili farkındalığın arttırılması hedeflenmektedir. Bu doğrultuda Çanakkale turizminin paydaşları ile görüşmeler gerçekleştirilmiştir. Görüşmeler sonucunda elde edilen bulgular doğrultusunda Çanakkale'nin dalış turizmi, SWOT analizi ile değerlendirilmiştir.

\section{Yöntem}

Çalışmanın amacı doğrultusunda dalış turizmi paydaşları ile mülakatlar gerçekleştirilmiştir. Ayrıca, katılımcı çeşitliliği için konuyla ilgili olduğu düşünülen farklı meslek gruplarından bilgi vermeye gönüllü olan kişiler örnekleme dâhil edilmiştir. Nitel araştırmalarda ortaya çıkan kavramlar ve süreçler birini tekrar etmeye başladığı zaman (doyum noktası) yeterli sayıda veri kaynağına ulaşıldığına karar verilir (Yıldırım ve Şimşek, 2011: 115). Bu çalışma kapsamında 11 kişi ile yarı yapılandırılmış görüşme gerçekleştirilmiştir. Katılımcılarla yapılan görüşmeler 12-30 dakika arasında sürmüştür ve Mayıs-Ağustos 2019 arasında yüz yüze gerçekleştirilmiştir.

Çalışmada elde edilen verilere betimleyici analiz ve içerik analizi uygulanmıştır. İçerik analizi; "Metodolojik araç ve teknikler bütünü, kontrollü yorum yapma, nesnel, sistematik ve nicel yollardan betimleme, önceden belirlenmiş ölçütlere göre inceleme, anlam çıkarma, açık talimatlara göre nicelleştirme işlemi, niteli nicele dönüştüren bir işlem, kavramların ölçülmesi ve belirli bir anlam çıkarılması için kategorilere ayırma", olarak tanımlanmaktadır (Tavşancıl ve Aslan, 2001: 21-22). Betimleyici analizde görüşülen bireylerin görüşlerini tam anlamıyla yansıtmak amacıyla sik sik doğrudan alıntılara yer verilmektedir (Yıldırım ve Şimşek, 2016: 239).

Geçerlik ve güvenirliği sağlamak için uygulanması gereken adımlar (Yıldırım ve Şimşek, 2016: 227) çalışmada aşağıdaki gibi uygulanmıştır.

- Amaçlı örnekleme gerçekleştirilmiştir.

- Katılımcılarla yapılan görüşmeler mümkün olduğunca uzun tutulmaya çalışmaya çalışılmıştır.

- Katılımcılarla gerçekleştirilen görüşmelerden doğrudan alıntılar gerçekleştirilmiştir.

- Yöntem çeşitleme (doküman analizi, görüşme) ve katılımcı çeşitliliği sağlanmaya çalışılmıştır.

- Kodlamalar farklı araştırmacılarla yapılarak karşılaştırılmıştır.

\section{Bulgular}

Katılımcılara ilişkin demografik özellikler Tablo 1'de gösterilmektedir. Bilimsel etik sebebi ile katılımcıların isimleri kodlanarak gizlenmiştir. Katılımcıların büyük çoğunluğunun erkeklerden oluştuğu görülmektedir. Bununla birlikte katılımcıların farklı yaş, eğitim düzeyi ve mesleklere sahip olduğu görülmektedir. Böylelikle, katılımcı çeşitliliğinin de sağlandığı söylenebilir. 
Tablo 1. Katılımcılara İlişkin Tanımlayıcı Bilgiler

\begin{tabular}{lllll}
\hline & Yaş & Cinsiyet & Eğitim & Meslek \\
\hline K1 & 53 & Erkek & Lisans & Troya Müzesi Müdürü \\
\hline K2 & 35 & Erkek & Lise & $\begin{array}{l}\text { Çanakkale Doğa ve Su } \\
\text { Sporları Kulüp } \\
\text { Başkanı/Dalgıç }\end{array}$ \\
\hline K3 & 43 & Erkek & Lise & Kaptan \\
\hline K4 & 35 & Erkek & Lisans & $\begin{array}{l}\text { Çanakkale Rehberler } \\
\text { Odası Başkanı }\end{array}$ \\
\hline K5 & 52 & Erkek & Ön Lisans & Dalış Eğitmeni \\
\hline K6 & 27 & Erkek & Lise & Abidos Travel Ortağı \\
\hline K7 & 45 & Erkek & Lisansüstü & Akademisyen \\
\hline K8 & 30 & Kadın & Lisansüstü & Dalgıç \\
\hline K9 & 40 & Erkek & Lisansüstü & $\begin{array}{l}\text { Troya Müzesinde } \\
\text { Arkeolog }\end{array}$ \\
\hline K10 & 42 & Erkek & Lisansüstü & $\begin{array}{l}\text { Çanakkale İl Kültür ve } \\
\text { Turizm Müdürlüğ̈̈ } \\
\end{array}$ \\
& & & Şube Müdürü \\
\hline K11 & 39 & Erkek & Lisansüstü & $\begin{array}{l}\text { Coğrafya Doktora } \\
\text { Öğrencisi- Arkeolog }\end{array}$ \\
\hline
\end{tabular}

Çalışmada mülakatlardan elde edilen veriler üzerinde betimsel analiz, içerik analizi ve kelime bulutu analizi uygulanmıştır. Uygulanan analizler sonucunda ulaşılan temalar Tablo 2'de gösterilmektedir. Her bir tema ve temayı oluşturan kodlar ayrı ayrı tablolaştırılarak sunulmuştur.

Tablo 2. Ulaşılan Temalara İlişkin Bulgular

\begin{tabular}{ll}
\hline No & Tema Adı \\
\hline $\mathbf{1}$ & Çanakkale'deki turizm faaliyetleri \\
$\mathbf{2}$ & Turist profili \\
$\mathbf{3}$ & Yeni turistik ürün talebi \\
$\mathbf{4}$ & Odaklanılması gereken turizm türleri \\
$\mathbf{5}$ & Su altı dalış turizmine ilişkin görüşler \\
$\mathbf{6}$ & Su altı heykel müzeleri ve arkeoparklara ilişkin \\
$\mathbf{7}$ & görüşler \\
\hline
\end{tabular}

Katılımcıların Çanakkale'de gerçekleştirilen turizm faaliyetlerine ilişkin görüşleri Tablo 3'te yer almaktadır. Çanakkale'de; deniz turizmi, kültür turizmi, dalış turizmi, gastronomi turizmi ve termal turizm gibi turizm türlerinin önemli olduğu belirtilmiştir.

Tablo 3. Çanakkale'deki Turizm Faaliyetlerine İlişkin Bulgular

\begin{tabular}{ll}
\hline Tema & Kodlar \\
\hline & \\
Çanakkale'deki & -Deniz-kum-güneş \\
turizm & turizmi \\
faaliyetleri & -Kültür turizmi \\
& -Dalış Turizmi \\
& -Gastronomi \\
& Turizmi \\
& -Termal Turizm \\
\hline
\end{tabular}

K6: "Çanakkale günübirlik turistin, Gelibolu şehitliklerini ziyaret ettiği yerdir."

K7: “...deniz turizmi üzerine gitmekte.”

K7: “Kültür turizmi Çanakkale'de ağırlıkla yapılmakta. Gelibolu, Truva, Assos gibi yerler de var."

K9: “Çanakkale'de deniz ve dalı̧̧ turizmi, gastronomi, sağlık turizmi (termaller: Çan, Yenice, Biga, Küçükkuyu,
Dalyan), kültür turizmi (tarihi alan, müzeler ve ören yerleri, kültür rotalarl yürüyüş ve bisiklet rotalarl), doğal ve doğa turizmi faaliyetleri (adalar, Ayazma, milli parklar, balıkçılık vb.) yapılmaktadır."

K10: "Her şey şehitlik gezilerinden ibaret, Troya gezisinden ibaret. Buraya gelenler kentten yalttlarak sadece Troya'yı gezip gidiyorlar."

K11: "Çanakkale'ye geldiklerinde onların kalmasını sağlayacak bir motivasyon aracı yok. Çanakkale'ye gelmek onlar için Troya'y görmek. Truya filmindeki atı görüp hemen gitmek. Şehitliği gezmek. İnsanların Çanakkale'de kalmasını sağlayacak sosyal kültürel alanlar yok. Gerekli alanlar olmayınca da insanlar bir açlik hissediyor"

Katılımcıların Çanakkale'de gerçekleştirilen turizm faaliyetlerinin yetersiz olduğu, çeşitlendirilmesi gerektiği ve potansiyelinin değerlendirilemediği yönünde görüş belirtikleri görülmüștür. $\mathrm{Bu}$ yönde görüș bildiren katılımcıların ifadeleri aşağıda sunulmuştur.

K6: “Çanakkale'de turizmi çeşitlendirebiliriz."

K6: “Kültür turizmi bir nebze de olsa uygulanıyor ama yeterli değil."

K7: “Çanakkale'de turizm faaliyetlerinin yeterli olmadığını düşünüyorum.",

K8: "Zaylf olduğunu düşünüyorum. Tek yönlü olduğunu düşünüyorum. O yüzden daha fazla şeyler yapılabilmeli."

K10: "Bence yeterli potansiyel işlenemiyor."

K11: "Çanakkale güçlü potansiyelini kullanamıyor. Çanakkale'de bugün çok güçlü bir deniz müzesi olması gerekirken yok. Askeri müze var ama Çanakkale'nin hak ettiği gibi bir müze değil bu. Çanakkale'nin devasa boyutlarda bir askeri müzeye ihtiyacı var. Kent Müzesi de bence çok küçük. Çanakkale'de Fevzi Paşa Mahallesi'nde eski palamut depolarl var. Orada eski tarihi dokusunu koruyarak bir kent müzesi yapllabilir, palamut ticaretini de gösteren. Burada çok güzel tuğla atölyeleri varmış. Arkeolojik kanitlardan bunların MÖ 2.3. yüzyıla kadar kullanıldı̆̆ını biliyoruz. Bu kültür 19. yüzyıla kadar devam etmiş. Ancak o atölyeler şimdi yok. O tuğlaları müzelerde görebiliyoruz. Çanakkale, kalesiyle ve çanağl ile ünlü bir yer. Çanakları da sunabileceğimiz bir müzeye ihtiyaç var. Çanakkale'nin bir de etnografya müzesine ihtiyacı var. Bugün Çanakkale'nin etrafindaki hemen hemen bütün kentlerde etnografya müzesi varken hatta küçük köylerde bile ama merkezde bir etnografya müzesi yok. Burada Yörükler çok özel bir kültüre sahipler. Halı dokumacılı̆̆ çok özel ancak bunlarl sunabileceğimiz bir etnografya müzesi yok. Çanakkale yüksek potansiyele sahip ancak bu değerlendirilmiyor. Bir hareket lazım"

Katılımcıların Çanakkale'yi ziyaret eden turistlere ilişkin görüşleri Tablo 4'te sunulmuştur. Katılımcılar; Çanakkale'yi çoğunlukla yerli turistlerin ziyaret ettiği, yabancı turistlerin ise Balkan ülkeleri turistleri olduğunu belirtmişlerdir. Bununla birlikte, gelen turistlerin ya günübirlikçi oldukları ya da 1 gece konakladıkları ifade edilmiştir. 
Tablo 4. Turist Profiline İlişkin Bulgular

\begin{tabular}{|c|c|c|}
\hline Cevaplar & Tema & Kodlar \\
\hline $\begin{array}{l}\text { K6: “Çanakkale daha çok } \\
\text { günübirlik ya da bir gece } \\
\text { konaklamalı turistlerin geldiği } \\
\text { bir yer” } \\
\text { K7: “Ağırlıklı olarak yerli } \\
\text { turist...” } \\
\text { K7: “AAdalarda özellikle } \\
\text { gözlemlediğim Bozcaada ve } \\
\text { Gökçeada'ya -özellikle } \\
\text { Gökçeada- Balkanlardan } \\
\text { turistlerin geldiğini } \\
\text { görmekteyiz. Saros Körfezine, } \\
\text { Bayramiç ve Yenice } \\
\text { taraflarına gittiklerini } \\
\text { görmekteyiz.” }\end{array}$ & $\begin{array}{l}\text { Turist } \\
\text { Profili }\end{array}$ & $\begin{array}{l}\text {-Günübirlikçi } \\
\text { - Yerli Turist } \\
\text { - Yabancı } \\
\text { turist } \\
\text { (Balkanlar) }\end{array}$ \\
\hline
\end{tabular}

Katılımcılar, turistlerin yeni ürün turistik talep ettiklerini belirtmişlerdir. Turistlerin yeni turistik ürün talepleriyle oluşturulan "Yeni Turistik Ürün Talebi" teması ve bu temayı oluşturan kodlar Tablo 5'te yer almaktadır.

Tablo 5. Yeni Turistik Ürün Talebine Yönelik Bulgular

\begin{tabular}{|c|c|c|}
\hline Cevaplar & Tema & Kodlar \\
\hline $\begin{array}{l}\text { K9: "Özellikle Yabancı fuarlarda } \\
\text { batıklara ilişkin dalı̧ turizmi } \\
\text { taleplerinin olduğuna tanık oldum. } \\
\text { Ayrica dağ ve doğa yürüyüşü ve Aziz } \\
\text { Paul Hac yolu güzergâhında Likya Yolu } \\
\text { gibi bir markalaşma talebi söz } \\
\text { konusudur." }\end{array}$ & Yeni & $\begin{array}{c}\text { - Dalış } \\
\text { - } \\
\text { Trekking }\end{array}$ \\
\hline $\begin{array}{l}\text { K2: "Şimdi dalış sporunu tatmış olan } \\
\text { insanlar Çanakkale'de bir dalış } \\
\text { yapalım bir batık görelim diyorlar. } \\
\text { Istanbul'dan bunun için bize çok ekip } \\
\text { geldi. Dalıs merkeziyle anlaşıp onlar } \\
\text { dalışa götürdük." }\end{array}$ & $\begin{array}{l}\text { turistik } \\
\text { ürün } \\
\text { talebi }\end{array}$ & $\begin{array}{l}\text { - Aziz } \\
\text { Paul Hac } \\
\text { yolu } \\
\text { - Likya } \\
\text { yolu }\end{array}$ \\
\hline $\begin{array}{l}\text { K3: "Yakın zamanda basslayan } \\
\text { Gökçeada'da rüzgâr sörfü var. Bir de } \\
\text { kitesurf var. Rüzgârından } \\
\text { faydalaniyorlar." }\end{array}$ & & - Kamp \\
\hline $\begin{array}{l}\text { K6: "Çanakkale'de kaz dağlarında } \\
\text { özellikle doğa turizmi, kamp işi bayağı } \\
\text { tutuluyor. Insanlar buna yöneliyorlar. } \\
\text { Kaz dağlarında hatta birkaç otel açıldı. } \\
\text { Deniz turizmi daha çok Bozcaada ve } \\
\text { Gökçeada bölgelerinde Çanakkale'yi } \\
\text { kapsamlı düşüneceksek evet deniz kum } \\
\text { güneş var. Yerli turistin talep ettiği } \\
\text { şeyler. Bunu yurt dışına da açabiliriz." }\end{array}$ & & \\
\hline
\end{tabular}

Katılımcılar, Çanakkale'ye yönelik yeni turistik ürün taleplerinin ancak arz yaratılması ile ortaya çıkacağını belirtmişlerdir. Katılımcılara göre turistik ürün ortaya konduktan sonra talep oluşmaktadır. K4 ve K5 kodlu katılımcılar bu yöndeki görüşlerini aşağıdaki gibi ifade etmektedirler;

K4: "Bizim arz etmemiz lazım en önemlisi o. Insanlar gördükleri yere gider. Afişlerde Assos, Truva, Bozcaada'ya gelirler sonra Çanakkale'yi gezdik diye bilirler. Ama keşfetmedikleri, görmedikleri birçok yerler vardır. Dolayısıla onlarin talepleri bizim sunduklarımızla sinırlıdır. Daha fazlası olamaz asla.”,

K5: "Biz önce diyoruz ki insanlar bir şey istesin biz ona göre tesisleşelim ona göre yatırımlar yapalım. Ama bu değil. Tabii önce yatırımı yapmak ondan sonra insanları buraya çă̆ırmak gerekiyor."

Katılımcıların Çanakkale'de turizmi geliştirmek için odaklanılması gereken turizm türlerine ilişkin görüşlerinin yer aldığı "Odaklanılması Gereken Turizm Türleri" teması Tablo 6'da sunulmuştur. Çanakkale'de turizmi geliştirmek için odaklanılması gereken turizm türlerine ilişkin bir görüş birliği olmadığı ve farklı farklı turizm türlerinin geliştirilmesi gerektiğine yönelik görüşlerin olduğu görülmektedir.

Tablo 6. Odaklanılması Gereken Turizm Türlerine İlişkin Bulgular

\begin{tabular}{|c|c|c|}
\hline Tema & Kodlar & Alt Kodlar \\
\hline \multirow{4}{*}{$\begin{array}{l}\text { Odaklanılması } \\
\text { gereken turizm } \\
\text { türleri }\end{array}$} & $\begin{array}{l}\text { Kültür } \\
\text { Turizmi }\end{array}$ & $\begin{array}{l}\text { - Savaşlar } \\
\text { - Şehitlik } \\
\text { - Troya }\end{array}$ \\
\hline & $\begin{array}{l}\text { Gastronomi } \\
\text { Turizmi }\end{array}$ & $\begin{array}{l}\text { - Yerel ve } \\
\text { yöresel } \\
\text { lezzetler } \\
\text { - Mutfak } \\
\text { turizmi }\end{array}$ \\
\hline & Spor Turizmi & $\begin{array}{l}\text { - Kite, } \\
\text { - Trekking, } \\
\text { - Rüzgâr } \\
\text { Sörfü, } \\
\text { - Jeep Safari, } \\
\text { - Yelkencilik } \\
\text { - Yamaç } \\
\text { Paraşütü, } \\
\text { - Dalış } \\
\text { - Dağcılık } \\
\text { - Kano }\end{array}$ \\
\hline & Agro Turizm & $\begin{array}{l}\text { - Hobi } \\
\text { bahçeleri } \\
\text { - Tarla } \\
\text { - Bağ } \\
\text { - Bahçe }\end{array}$ \\
\hline
\end{tabular}

K2: “Çanakkale'de görülebilecek o kadar çok yer var ki. Mesela yürüyüs sporu için bir güzergâh çizilse yani buradan yorgun değil de memnun ayrllırlar. Çünkü insanın yürüdüğü yol değil gördüğü güzellikler ileriye doğru götürüyor. ",

K1: "Kültür turizmi, savaşlar, doğa yürüyüşü ve kırsal turizme odaklanılmalıdır."

K2: "Kitesurf daha güzel, daha mantıkll, daha heyecanlı bir spor. Onun için özel bir bölge var. Ísteseniz o spor için öyle bir bölge yaratmanız mümkün değil. Doğal bir oluşum var. Rüzgâr hiç kesmiyor. Her zaman esiyor."

K3: "Rüzgâr, dalış, dăgcıllk, deniz ürünleri. Ancak mutfak turizminde de fiyat politikalarımız çok kötü. Bozcaada senelerdir büyüyen bir yara olarak duruyor orada turizm konusunda"

K4: "Kültür turizmi, ekstrem sporlar olabilir. Bence gastronomide eksiklik var. Gastronominin geliştirilmesi gerekir. Yerel, yöresel lezzetler.”

K6: "Bence birincisi av turizmi ikincisi de dalış turizmi"

K7: "Spor turizmi kesinlikle olmall." 
K8: "Kaz dağlarl gibi bir unsuru var. Doğa turizmi yapılabilir kano ile yapılabilen sporlar da yapılabilir. Extreme sporlar da yapllabilir. Trekking yapılabilir."

K8: "Doğa turizmi, dalış turizmi. Çünkü batık olarak da daha iyi su altı canlılı̆̆ da güzel bir yer burası. Trekking olabilir."

K8: "Mesela hobi bahçeleri kurulabilir. Bayramiç taraflarında tatile gelen, kafasını dinlemek isteyen insanlara böyle bir tarla bahçe bağ ile kendi meyvesini toplama imkânı verilebilir. Çok da güzel sonuçlar alınacağını düşünüyorum ben."

En çok hangi turizm türlerinden bahsedildiğini belirlemek için kelime bulutu (wordcloud) analizi uygulanmıștır. En çok tekrar eden 2 kelime üzerinden kelime bulutu analizi gerçekleştirilmiştir. Kelime bulutunda tekrar sayısı artan kelimeler en büyük ve koyu; en az olanlar ise en küçük koyu olmayan bir punto ile gösterilmektedir. Uygulanan kelime bulutu analizi sonuçları Şekil 1'de gösterilmektedir.

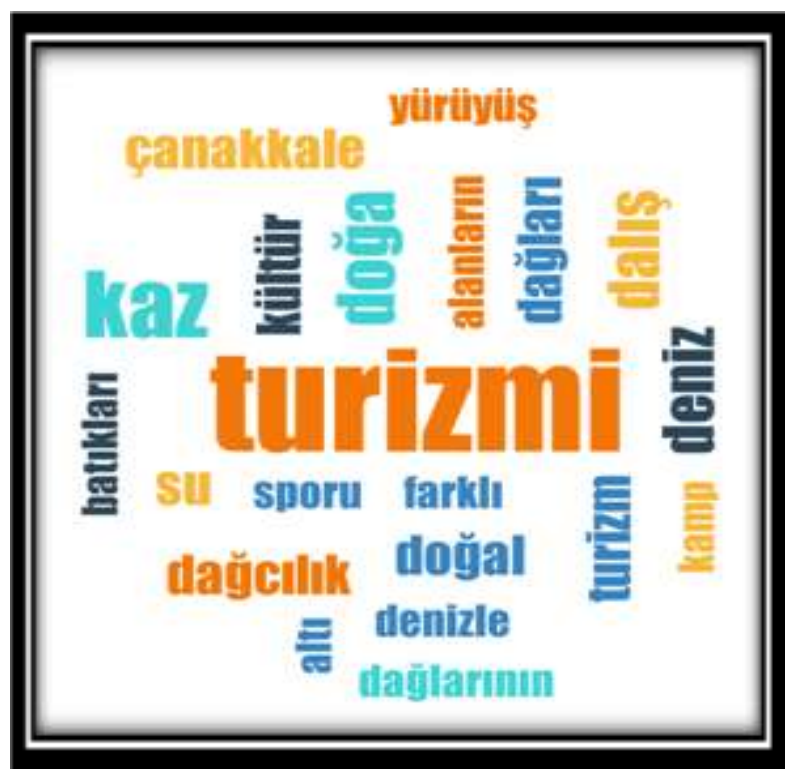

Şekil 1. Odaklanılması Gereken Turizm Türleri Kelime Bulutu Analizine İlişkin Bulgular

Katılımcıların odaklanılması gereken turizm türlerini; "doğa, dağcılık, dalış, deniz, yürüyüş" kelimeleri ile ifade ettikleri görülmektedir. Tablo 6 incelendiğinde, gerçekleştirilen içerik analizi ve betimsel analiz sonucunda ulaşın kod ve temaların da bu doğrultuda oluştuğu görülmektedir.

Katılımcıların su altı dalış turizmine ilişkin görüşleri "Su altı dalış turizmine ilişkin görüşler" teması altında toplanmış ve temaya ilişkin kodlar ve alt kodlar Tablo 7'de raporlanmıştır.
Tablo 7. Çanakkale'de Su Altı Dalış Turizmine İlişkin Görüşler Temasına İlişkin Bulgular

\begin{tabular}{|c|c|c|}
\hline Tema & Kodlar & Alt kodlar \\
\hline \multirow{3}{*}{$\begin{array}{l}\text { Çanakkale'de Su } \\
\text { altı dalış } \\
\text { turizmine ilişkin } \\
\text { görüşler }\end{array}$} & Engeller & $\begin{array}{l}\text { - Akıntı } \\
\text { - Yasal engeller } \\
\text { - Boğaz trafiği } \\
\text { - Derinlik } \\
\text { - Uluslararası gemi } \\
\text { geçişleri }\end{array}$ \\
\hline & $\begin{array}{l}\text { Yapilabilecek } \\
\text { Yerler }\end{array}$ & $\begin{array}{l}\text { - Kaptan Franco } \\
\text { - Kapukinka } \\
\text { - Tavşan Adası, } \\
\text { Bozcaada } \\
\text { - Konteynır, } \\
\text { Bozcaada } \\
\text { - Havuzlar mevki } \\
\text { - Soğanlı Dere } \\
\text { - Baykuş Dere } \\
\text { - Asos } \\
\text { - Güzelyalı } \\
\text { - Lundy } \\
\text { - Su Arıtma Gemisi } \\
\text { - Carthage } \\
\text {-Majestik } \\
\text { - Midilli Breslau } \\
\text { - Anzak Koyu } \\
\text { - Eceabat }\end{array}$ \\
\hline & $\begin{array}{l}\text { Gerçekleştirilen } \\
\text { Dalış Faaliyetleri }\end{array}$ & $\begin{array}{l}\text { - Çalıştay } \\
\text { - Tanıtıcı (discover) } \\
\text { dalış } \\
\text { - Dalış okulları } \\
\text { - Akıntı dalışı }\end{array}$ \\
\hline
\end{tabular}

K2: Ticari bir gemimiz var Kaptan Franco 45 metrede. Asfalt malzemesi taşırken bir gemiyle çarpışması sonucu havuzlar mevkiinde karaya giderken batıyor. İstanbul'dan gelen ekibi bu gemiye daldırmaya çalışıyoruz. Ama aslında daldıramıyoruz. Çünkü akıntı var, görüs net değil insanlara 45 metre dendiği zaman herkeste ayn yeterlilik yok."

K9: "Boğazda turistik dalış potansiyeli düşüktür (Boğaz Trafiği, derinlikler, akıntı ve bilinen nedenlerle...)",

K2: "Bide boğaz içerisinde bazı gemi geçişlerine engel olacă̆ından dolayı su sporlarına izin verilmiyor. Yani adrenalin sporlarını burada yapamıyorsunuz. Turist çekemiyorsunuz. Paraşüt yapamıyorsunuz. Bu boğaz olduğu için hani gemilere engel olur, problem olur, sikıntı yaratır diye önü kesilmiş durumda kesinlikle izin verilmiyor."

K10: "Eski bir gemi batırllabilir. Yabancılar I. Dünya savaşında batan gemilere dalış yapmak istiyorlar. Ama Çanakkale boğaz olması sebebiyle birtakım şeyler var. Batıklar var ama her batığa izin verilmiyor. Biz orada 3 tane batık belirledik. Franco batıklarl su anda izinli. Hem akıntıdan dolayı hem de 30 metrenin altına herkes dalıș yapamıyor. Çoğu batık da 30 metrenin altında. Uluslararası gemi geçişlerinin olduğu bir boğazda siz durun ben dalış yapacă̆ım diyemiyorsunuz. Ayrıca alan başkanlı̆̆ının sorumluluk sahasında kalıyor. Alan başkanlığl dalışa izin vermiyor. Biz gerekli çallşmalarl yaptıktan sonra izin verilebilir diyor. Bu gibi sebeplerden dolayı batıklara dalış zor." 
K1: "Su altı çalıștayı yapıldı geçen sene."

K2: "Seviyeye göre her bölgenin farklı seviyeleri var. 1 yıldız için şurası deriz. 2 yıldız için burası deriz. Çanakkale'nin boğaz içerisinde discover dediğimiz tanıtıcı dalış var. Herhangi bir evraka gerek yok. Ĕgitmenler beraber suya atlar. Ĕgitmen seviyesini belirler yeterliliğe göre 5 metreye kadar gezdirir, çıkartır. Adam memnundur. 1 yıldızı vardır. 15 metreye kadar dalıs yapılır. Sorarız ne görmek istersin balık mı batı mı? O seviyeye uygun yer de var. 2 yıldız içinde uygun yer var. Çanakkale Boğazı çok büyük bir boğaz, çok geniş bir boğaz."

K3: "Limandan bile dalış yapılacak birkaç yer var. Mesela Kaptan Franco diye bir asfalt gemisi var. Onun altında 73 metrede hayvan gemisi var. Bunlar gibi saymakla bitmeyecek birçok batık var. Bozcaada civarında var. Tavşan Adası civarında batıklar var. En son batı Bozcaada'nın 4 mil güneybatısında gemi var. Konteynir denilen. Derinliği gayet iyi 45 metre tabanı, 27 metre üst seviyesi geminin."

K8: “Çanakkale'de gayet uygun yerler var. Havuzlar mevki var, Soğanlı Dere var, Baykuş Koyu var, Asos taraflarında güzel yerler var, canlılığın bulunduğu Güzelyalı tarafinda var."

K11: "Suyun altı batık cenneti. Ama o batıklardan bazlları turizme kazandırlabilir batıklar. Herkesin dalabileceği yerler var. Mesela Saros Körfezi'nde böyle yerler var. Anzac Koyu tarafinda 20-25 metre altta batlklar var. Bunun ötesinde bu bölge balıklarlyla tanınır. Çanakkale balıkları ziyaret eden dalgıçlar içinde çok özel alanlardır. Örneğin Asos ve Saros bölgesi bu anlamda bir akvaryumdur. Tanıdı̆̆ım dalgıçların anlattıklarına göre çok keyifli dalma hikâyeleri var"

K11: "Eceabat Gelibolu tarafinda belki Eceabat'ın koyunda olabilir. Troya'ya doğru koylarda olabilir. Anzak Koyu civarında olabilir."

$\mathrm{Su}$ altı heykel müzeleri, su altı arkeoparkları ve turizm gelişimine etkilerine ilişkin görüşler Tablo 8'de sunulmuştur. Su altı heykel müzeleri, su altı arkeoparklarına yönelik olarak olumlu yönde olduğu gibi olumsuz yönde de görüşler bulunmaktadır.

Tablo 8. Su Altı Heykel Müzeleri ve Arkeoparklar

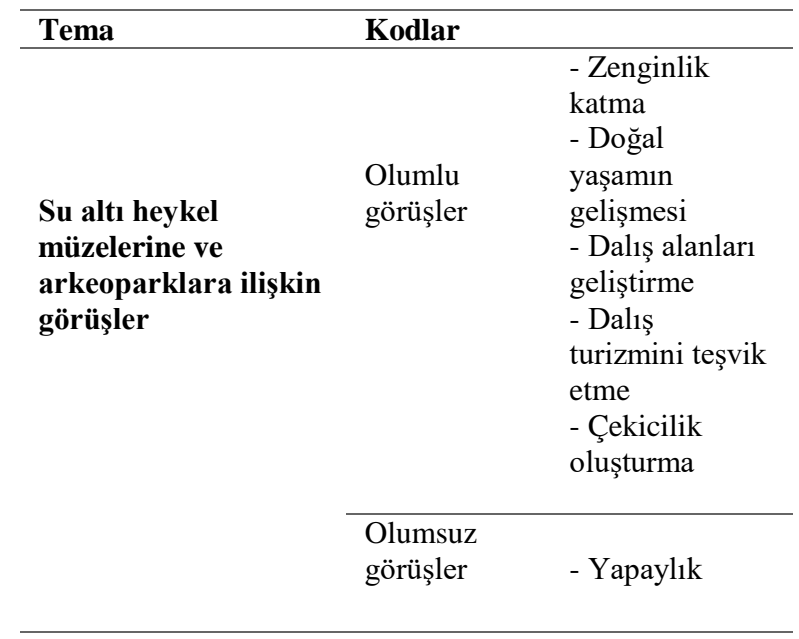

K1: "Yapılmasl gerektiğini düşünüyorum. Zenginlik katar. Değişiklik de talebi olumlu yönde etkiler."

K2: “Heykel müzeleri artık çok yaygınlaşıyor. Çünkü resifler bozuluyor insanlar denize girdiklerinde ot görmek istemiyorlar. Bir şeyler görmek istiyorlar. Yapay olsun heykel olsun."

K3: "Çanakkale'de olmamall. Yapay diyorsanı o olmaz. Batıklarımız yapay parklardan çok çok iyi"

K5: "Su altı arkeoparklart ve su altı heykel müzeleri ya da su altına yapılmış herhangi batıklar konusunda su altındaki canlıların oluşabilmesi için canlıların bir karakterleri vardır hep sert objelerin yanında olmak isterler. Bu niye işte kayalar taşlar ya da batıklar vesaireler bu tür şeylerin yanında olmak isterler. Çünkü orada saklanabilecekleri üreyebilecekleri eşleşebilecekleri bir sürü alanlar vesaireler olduğu için bunu isterler. Dolayısıyla yapılması gereken bu tür arkeoparklar ya da heykel müzeleri bunlar daha çok flora ve faunanın, su altı canlılı̆̆ının az olduğu ya da olmadığ noktalarda yapılmasi gerekir."

K9: "Evet, kesinlikle katkısı olacaktır, en azından eğitim ve dalış zevki oluşturmak adına; belirlenmiş ve uygun görülen alanlarda eski bir uçak belki bir tank ya da Troya savaşı kahramanlarına ait heykellerden birkaç dalış lokalizasyonu oluşturmak mümkündür. Su altı arkeoparkı oluşturmak için ise ÇOMÜ Su Altı Arkeolojisi Bölümü ve Restorasyon bölge laboratuvar kurmak öncelikli olmalıdır. Çanakkale'den önce Konya'da su altı arkeolojisi bölümü kurulması yurdumuzun ironi yüklü bir anısı değilse nedir?"

K11: "Su altında heykel yaratılmış bir turizm gibi geliyor bana. Bu kültür turizmine gelen insanlarl tatmin etmez. Orada gerçekten bir heykel yoksa ya da bir antik kent yoksa oraya koyduğunuz birkaç heykelle haber kaynaklarını ya da birkaç turist çekersiniz. Eklektik turizmden yana değilim. Çanakkale'nin de eklektik turizme ihtiyacr yok. Çanakkale kendi potansiyelini açığa çıkarırsa zaten fazla fazla yeter."

K10: “Antalya'da yapay uçak batırıldı. Çanakkale'de de neden olmasın. 30 metreyi geçmeyecek şekilde uçak, gemi veya tanker batırllabilir. Bununla dalış turizmi teşvik edilebilir."

Katılımcıların dalış turizminin gerçekleştirilen bölge üzerinde etkilerine ilişkin görüşlerini ifade eden "Su altı dalış turizminin bölge üzerindeki etkileri” teması Tablo 9'da raporlanmıştır.

Tablo 9. Dalış turizminin bölge üzerindeki etkileri

\begin{tabular}{cc}
\hline Tema & Kodlar \\
\hline Su altı dalış & - Destinasyona \\
yönelik turistik \\
turizminin bölge & talep yaratma \\
üzerindeki & - Gelir yaratma \\
etkileri & etkisi \\
& - Destinasyon \\
& tanitimina katkı \\
& - Bölgedeki \\
& turizmi \\
& çeşitlendirme \\
& - Doğal yaşam \\
& üzerinde olumsuz \\
& etki
\end{tabular}


K2: "Bölgeyi kalkındırır. Çünkü dalış yapan zengindir. Dalış yapmaya gelen adam sadece dalış yapıp gitmez. Akşam güzel bir yemek yer. Deniz gören otelde güzel bir gece geçirir. Sabah güzel bir kahvaltı eder. Buradan dönerken Çanakkale'ye ait ne varsa alıp götürür."

K5: "Dalış turizminin bölgeye faydası olur. Sonuçta buraya 10 tane turist getirdiniz düşünün bir otelde kalacaklar bir restoranda yemek yiyecekler bir balık yiyecekler ya da kalkacaklar oradan bir misir yiyecekler ya da bir simit alacaklar ya da bir tuvalete girecekler... Sonuçta her türlü şekilde Çanakkale'ye artıları vesaireleri vardır mutlaka ve mutlaka bir faydası vardır"

K3: "Tabi ki var bilinçsiz dalgıçlar özellikle gece dalanlar su altını tahrip ediyorlar. Hayvanları ürkütüyorlar. Yuvalarını terk ediyorlar. Üzerlerine çöp atılıyor. Attığımız çöpler oradaki canliyı rahatsı ediyor. Ve oradan ayrllmasina neden oluyor."

Katılımcıların dalış turizminin bölgedeki turizm faaliyetlerine katkı sağlayacağı yönünde görüşe sahip oldukları söylenebilir. Destinasyonun tanıtımına katk1 sağlayacağı, turistik çekicilik oluşturacağı, bölgedeki turizmi çeşitlendireceği, bölgeye yönelik turistik talep yaratacağ1 yönünde görüş bildirdikleri ifade edilebilir.

K2: "Yani biz insanları en fazla 4 saat tutuyoruz. Geri kalan zamanda Çanakkale'yi gezerler uyurlar, alışveriş yaparlar, fotoğraf çekerler, Çanakkale 'yi reklam yaparlar."

K6: "Yerli ve yabancl turist çekme konusunda alternatif olabilir."

K7: "Turizmi çeşitlendirir. Turizm türlerini çeşitlendirerek Çanakkale'de insanların daha uzun kalmalarını, Çanakkale'yi de bir destinasyon haline getirmelerini sadece denize değil kültürel değil, sportif amaçla da gelinebileceğini gösterir. Bulgaristan'dan gelen insanlarda çok görüyoruz. Gökçeada'ya sirf bunun için gelenleri görebiliyoruz. Ulaşımda eskisine göre çok daha kolay çeşitlilik olur. Bölge canlanır. Elimizdeki potansiyeli kullanmış oluruz. İsgücü yaratır. Pek çok sosyo-ekonomik faaliyete etkisi olur."

K11: "Yeni bir turistik grubu çeker. Şehitliğe antik kentlere gelenler belli. Turisti çeşitlendirir. Deniz turizmiyle \%1015 'lik bir artış olacağını düşünüyorum "

K4: "Vardır ama lokomotif olamaz hiçbir zaman. Çünkü günümüzde de kaç kişi dallyor. Yani sokaktaki insanların yüzde kaçı su altı sporlarına ilgili. O kadar oranda ekstra bir katkl yaratılır. Sadece alternatif olabilir. Çeşitlilik arz edebilir. Ekstra katkl getirebilir ama lokomotifi burada diyemeyiz hiçbir zaman. Bir Truva'yl Assos'u, şehitliği, buranın kültürünü bertaraf edip de öne geçemez hiçbir zaman."

Katılımcılar bir yandan dalış turizmi faaliyetlerinin bölge üzerinde olumlu etkilere sahip olacağını belirtirken diğer yandan da doğal yaşam üzerinde bazı olumsuz etkiler ortaya çıkabileceğini de vurgulamaktadır. Dalış turizmi faaliyetlerinin bilinçli bir şekilde gerçekleştirilmesi ile bu olumsuz etkilerin önüne geçilebileceği belirtilmektedir. Ek olarak dalış turizminin değil de avcılığın doğa üzerinde daha olumsuz etkilere sahip olduğunu vurgulandığı da görülmektedir. Bu noktada tüplü dalışın eğitimli kişilerce gerçekleştirildiğinde doğaya herhangi bir zarar vermeyeceği sonucunu çıkarmak da mümkün olabilmektedir. Bu yöndeki katılımcı görüşlerinin örneklerine aşağıda yer verilmiştir.

K3: "Dalış yaptın bir taşı oynatın altında yuvası vardı. Bilemezsin orada yuva olduğunu. Yani zarar vermek çok kolay. Dikkatli olduğunuz sürece zarar vermezsiniz."

K5: "Bizim onlara verebileceğimiz zarardan çok çok fazla avcllkta verilen zarar var"

K5: "Tüplü dallşın doğaya bir zararl yoktur. Çünkü biz bir tüplü dalıcıyı yetiştirirken yaklaşık 10 saat teorik ders veriyoruz. Bu verdiğimiz derslerin içerisinde; su altı dalış bölgesi seçimi, su altı canlıların korunması ve su altının flora ve faunasi hakkında bilgiler veriyoruz. Yani suyun altından sadece fotoğraflarımızı ve anılarımızı alıp çıkmamız gerektiğini anlatıyoruz eğitimlerde. Dolayısıla işte bu ĕgitimi almış birisinin su altından bir kabuğu bile alması düşünülemez. Biz bir çöpü alırken bile a orada bir canlı var mı yerleşmiş mi deyip onu sirkeleyip temizleyip ondan sonra allyoruz. $O$ çöp alırken bu düşünce içerisinde hareket ediyoruz ve öğrencilerimize ĕgitim verdiğimiz kişilere bu bilinci aşıllyoruz. Şimdi bu bilinçle yetişmiş bir kişi su altından sadece fotoğraf karelerini fotoğraflarını çeker ve fotoğrafları ile çıkar. Asla ve asla doğaya zararlı olduğunu düşünmüyorum."

K8: "Şöyle ki tüplü dallşta kurallarına uyarsanız herhangi bir zararı yoktur. Yani çıplak elle canlılara dokunmadığın sürece herhangi bir zararl yoktur ki çoğunlukla da elleseniz de zararl yoktur. Ama bilemezsiniz elimizdeki bakterinin o canlının savunma sistemini uygun olup olmadiğın bilemezsiniz. O yüzden dokunmadan yaptığımız dalışlarda herhangi bir problem yok. Hatta faydası bile var. Çoğu kez plastik ürün vesaire de çıkarttı̆̆ımız oluyor. Çünkü tüplü dalışı amacı zaten hiçbir şeye dokunmamaktır. Yani dalış yaptığımı hiçbir şeye dokunamazsınız sudan çıkaramazsınız çöp dışında. O yüzden herhangi bir zararl olmaz."

K10: "Zararı olduğunu düşünmüyorum. Ama dalışların kontrollü yapılmasından yanayım. Ya kimse ellemez, bir şey olmaz, ne olacak ki! Beni ilgilendirmez. Dalış kontrollü olmalı ki biz bunu gelecek kuşaklara aktaralım. Adam baktı ortam müsait bir parça aldı götürdü. Ya da yerini değiştirdi. Özellikle batıklara kontrollü dalış yapılmasından yanayım.",

K11: "Dalış belli kurallar çerçevesinde yapılırsa bence zararlı değil. Batı̆̆a yaklaştıklarında dikkat etmeleri lazım balıklar açısından bazı bölgelerde balıklar yuvalansın diye de bazı gemiler ya da uçaklar batırılabiliyor."

Bazı katılımcılar insan sağlığı açısından ortaya çıkabilecek olumsuz sonuçlara da değinmişlerdir. Bu görüşlere aşağıda yer verilmiştir.

K3: "Insan sağlı̆̆ı açısından bilinçsizce yapılan her türlü dalış tehlikeli ve zararlıdır. Su altında basınç dengelemeyi beceremezseniz kulak zarl da patlar. Ciğerler de zarar görür. Şoka girersiniz."

K8: "Hayır. Eğitimini aldı̆̆ınız hiçbir şeyin zararı yoktur. Yani bir atletizmde yaşayacă̆ız problemler dallşta da vardır tabii her sporun riski var. Ama bildiğin bir şey asla zararlı olmaz" 


\section{Sonuç ve Öneriler}

Çanakkale'de deniz-kum-güneş turizmi, kültür turizmi, dalış turizmi, gastronomi turizmi ve termal turizminin gerçekleştirildiği belirlenmiştir. Ancak bu turizm faaliyetlerinin yetersiz olduğu ve çeşitlendirilerek potansiyelinin kullanılması gerektiği tespit edilmiştir. Ulaşılan bu sonuç, ilgili alanyazında benzer bulgular ortaya koyan çalışmalar ile örtüşmektedir. Kelkit (2003) ile Genç vd. (2014) Çanakkale'nin turizm potansiyelinin yüksek olduğunu, ancak bu potansiyelden yeterince faydalanamadığını vurgulamaktadırlar.

Çanakkale'ye gelen turistlerin; yerli turistler ve günübirlikçiler ile Balkanlar'dan gelen yabancı turistlerden oluştuğu görülmektedir. Benzer şekilde, Çakıcı ve diğerleri (2006) yerli turistlerin ortalama 1,6 geceleme yaptığ1, yabancı turistlerin ise ortalama 1,1 gece konakladığını tespit etmişlerdir. Çalışma bulgusundan farklı olarak Çakıcı vd. (2006) en çok konaklayan ülkelerin ise sırasıyla Almanya, Japonya, Amerika ve Benelüks ülkeleri olduğunu tespit etmiştir. 2013 verilerine bakıldığında en çok gelen ülkelerin sirasiyla ABD (21.673), Avustralya (18.699), Çin (14.108), Japonya (8.842) ve Almanya (6.449) olduğu görülmektedir. Gecelemenin ise yabancilarda 1,10 , yerlilerde ise 1,60 olduğu görülmektedir. 2018 verilerinde ise büyük bir farklılık olduğu görülmektedir. 2018'de Çanakkale'yi en çok ziyaret eden ülkeler sırasıyla Çin (46.634), Tayvan (15.868), Romanya (13.285), Tayland (9.034) ve Malezya (8.165) olduğu görülmektedir. Bununla birlikte yabancıların 1,34, yerlilerin ise 1,76 geceleme yaptığ $\breve{1}_{1}$ görülmektedir (Çanakkale İl Kültür ve Turizm Müdürlüğü, 01.04.2019).

Turistlerin Çanakkale'de yeni turistik ürün taleplerinin ortaya çıktığını söylemek mümkündür. Bu doğrultuda, dalış, trekking, Aziz Paul Hac Yolu, Likya Yolu, sörf ve kamp ön plana çıkmaktadır. Günümüzün turizm talep eğilimleri, yeni ve farklı deneyimler, otantik deneyimler ve macera yaşama yönündedir. Turistlerin turizm ürününden beklentileri; kültür ve bilgi düzeyini arttırması, eğlenceli ve kaliteli bir boş zaman değerlendirmesi yönünde olmaktadır (Bozic ve Berić, 2013). Aziz Paul Hac Yolu'nun inanç turizmi açısından önem arz ettiğini söylemek mümkündür (Erçolak vd., 2019). Yapılan bir araştırmada, Likya Yolu'nu yürüyen turistlerin seyahat motivasyonlarının sosyalleşme ve kendini gerçekleştirme, bağımsız seyahat etme, dünyayı tanıma, deneyim arayışı ve sakinlik arayışı olduğu tespit edilmiştir (Akgündüz ve Kızılcalığlu, 2016).

Çanakkale'de turizmin gelişimini sürdürebilmesi için; kültür turizmi, gastronomi turizmi, spor turizmi, tarım (agro) turizm ön plana çıkmıştır. Kelkit (2003) Çanakkale'nin macera turizmi, din turizmi, kültür turizmi, termal turizm, gençlik turizmi ve ekoturizm potansiyelinin bulunduğunu eklemiş ve bu potansiyelin açığa çıkarılması için teknik altyapı yatırımlarına ağırlık verilmesi gerektiğini belirtmiştir. Köseler vd. (2019), Çanakkale bölgesi için üç alternatif gastronomi rotası önermişlerdir. Bu rotalar, et ve süt ürünleri için, Biga, Bayramiç, Ezine, Gökçeada; deniz ürünleri için, Gelibolu, Çanakkale merkez, Bozcaada ve Gökçeada; şarap tadımı için, Gelibolu, Eceabat, Çanakkale merkez, Bozcaada ve Gökçeada Çanakkale'de dalış turizminin gelişiminin sağlanması için bazı faaliyetlerin yürütüldüğü görülmektedir. Bununla birlikte, Kaptan Franko, Kapukinka, Tavşan Adası-Bozcaada, Konteynır-
Bozcaada, Havuzlar Mevki, Soğanlı Dere, Baykuş Dere, Asos, Güzelyalı, Lundy, Su Arıtma Gemisi, Carthage, Majestik, Midilli Breslau, Anzak Koyu ve Eceabat dalış yapilabilecek yerler olarak ele alınmaktadır. Ancak Çanakkale'nin su altı zenginliği sadece buralardan ibaret değildir. Turistik dalışların 30 metreden az derinlikte yapılması gerekmektedir (Yarmacı vd., 2017: 67) ve birçok batık 50 metrede veya daha derinlerdedir. Özalp (2004) çalışmasında bu sorunun birçok batığa dalış yapılamamasına neden olduğunu belirtmiştir. Bu durum, birçok batığın incelenmesi ve Çanakkale'de var olan dalış turizmi potansiyelinin değerlendirilmesi yönünde bir engel oluşturmaktadır.

Akıntının, boğaz trafiğinin, derinliğin ve yasal uygulamaların Çanakkale'de yapılabilecek dalış faaliyetleri önünde engeller oluşturduğu belirlenmiştir. Özalp (2004) batıkların derinliğinin kuvvetli boğaz akıntısının ve gemi güzergâhının dalış faaliyetlerini zorlaştırdığını belirtmiştir. Özbek (2014) ise su sporları ile ilgili yaptığı çalışmasında daha farklı sonuçlara ulaşmıştır. Su sporları işletmesinin faaliyet gösterebilmesi için Kültür ve Turizm Bakanlığı'ndan, Ulaştırma Denizcilik ve Haberleşme Bakanlığg'ndan, Maliye Bakanlığı'ndan, Çalışma ve Sosyal Güvenlik Bakanlığı'ndan, bağlı bulunulan belediyelerden, ilgili federasyonlardan ve faaliyette bulunulan tesisten izin almaları ve bu kurumlardan belli evrakları toplamaları gerekmektedir. Bu doğrultuda en önemli sorunun bürokratik zorluklar olduğunu belirtmiştir. Diğer sorunlar ise; denetim eksikliği, finansal sorunlar, sezonun kısa olması, her şey dâhil sistemi ve son olarak nitelikli eleman sıkıntısı olduğu vurgulanmıştır.

Çanakkale'de yapılacak su altı heykel müzeleri ve arkeoparkların zenginlik katma, doğal yaşamın gelişmesine katkı sağlama, dalış alanları geliştirme, dalış turizmini teşvik etme ve çekicilik oluşturma gibi olumlu fonksiyonlarının olduğu söylenebilir. Yaşar (2011), Çanakkale bölgesinde Saros Körfezi’nde uluslararası bir çekim yaratılması için yapay resif ve su altı tarih müzesi gibi projelerin desteklenmesi gerektiğini belirtmiştir. Bir diğer çalışmada Erkurt ve Paker (2014) Türkiye'nin su altı zenginliğinin görülebilmesi gerektiğini ve bunun için su altı arkeoparkları, imitasyon müzeler gibi projelerin hayata geçirilmesinin önemli olduğunu ve böylelikle, geniş kitlelere ulaşılabileceğini belirtmiştir. Su altı fauna ve florası zengin olan ve Kaş ilçesinde yer alan arkeoparkların, destinasyona yönelik talebi arttırmakta olduğu tespit edilmiştir (Erkurt ve Paker, 2014: 134). 2015 yılında Side'de açılan Türkiye'nin ilk su altı müzesinde yaz-kış dalış yapılabilmekte ve müzeyi 100 bine yakın yerli ve yabancı turist ziyaret etmektedir. Bununla birlikte heykeller, denizin doğal yaşamına zarar vermeyecek şekilde yerleştirilmiş olduğu ifade edilmektedir (https://www.cnnturk.com).

Çanakkale'de dalış turizminin geliştirilmesinin bölge üzerinde olumlu etkiler yaratabileceği tespit edilmiştir. $\mathrm{Bu}$ olumlu etkilerin, turistik talep yaratma, gelir yaratma etkisinin ortaya çıkması, Çanakkale tanıtımına katkı sağlaması ve bölgedeki turizmi çeşitlendirme yönünde olacağı belirlenmiştir. Literatürde özellikle dalışın gelir yaratma etkisine vurgu yapılmış ve dalışın kalkınmaya fayda sağlayacağı belirtilmiştir (Yarmacı vd., 2017). Dalış turizmi faaliyetlerinin bölge üzerinde olumlu etkilere sahip olacağını belirtirken diğer bir yandan da doğal yaşam üzerinde bazı 
olumsuz etkiler ortaya çıkabileceği ifade edilebilir. Bu olumsuz etkilerin, tüplü dalışın eğitimli kişilerce gerçekleştirilmesi ile önüne geçilebileceği sonucunu çıkarmak da mümkün olabilmektedir. Hasler ve Ott (2008) tüplü dalışın yoğun olduğu bölgelerde resifleri olumsuz etkilediğini tespit etmiştir. Yarmacı vd. (2017) ise, dalış turizminin eğitimli kişiler tarafından yapıldığ 1 için çevreye zararı olmadığını belirtmiştir. Bununla birlikte sağlanan gelire büyük faydası olduğu vurgulanmıştır. Benzer şekilde Hammerton (2017) de dalgıçların eğitim seviyesinin hassas resif alanlarının yönetimi ve korunması için önemli olduğunu ifade etmektedir. Bir başka çalışmada Sevinç ve Özel (2018) boş zaman aktivitesi olan dalış turizminin çevresel sürdürülebilirliğe olumlu bir etkisi olduğunu çünkü yeni turist profilinin çevreye duyarlı olduğunu belirtmiştir.

Çalışmada ulaşılan verilere yönelik gerçekleştirilen analizlerden elde edilen bulgular doğrultusunda Çanakkale'nin su altı dalış turizmi SWOT Matrisi oluşturulmuş ve bu matris Tablo 10'da sunulmuştur. Bu doğrultuda Çanakkale'nin dalış turizmi açısından güçlü ve zayıf yönlerinin olduğu bununla birlikte bazı firsatlara sahip olduğu ve bazı tehditlerle karşı karşıya olduğunu ifade etmek mümkündür.

Tablo 10. Çanakkale'nin Su Altı Dalış Turizmi SWOT Matrisi

\begin{tabular}{ll}
\hline Güçlï Yönler & Zayıf Yönler \\
\hline - Su altı dalış & - Dalış \\
gerçekleştirilecek alanlar & gerçekleştirilebilecek \\
açısından zenginlik & uygun derinlikli \\
- Su altı dalışa yönelik & alanların sınırlı olması \\
talebin bulunması & - Denizde akıntının bulunması \\
- Su altı dalışın & - Dalış turizminin önünde yasal \\
gerçekleştiriliyor olması & engeller bulunması \\
- Dalış okullarının & - Boğazdaki gemi trafiği ve \\
bulunması ve eğitim & uluslararası gemi geçişleri \\
verilmesi & \\
- Dalış turizmini & \\
geliştirmeye yönelik & \\
faaliyetlerin & \\
gerçekleştirilmesi & \\
- Zengin su altı dalış & \\
turizmi kaynaklarının & \\
bulunması & \\
\hline Fırsatlar & Tehditler \\
\hline - Turistik ürün talebinde & - Kaçak gerçekleştirilen \\
yaşanan değişimler & balıkç1lık faaliyetleri \\
- Bölgede gerçekleştirilen & - Çevre ve doğal yaşam \\
turizm faaliyetlerini & üzerinde ortaya çıkabilecek \\
çeşitlendirme & olumsuz etkiler \\
- Gelir yaratma etkisi & - Eğitimsiz dalışlar \\
ortaya çıkarma & \\
- Destinasyon tanıtımına & \\
katk1 & \\
- Yeni talep yaratma & \\
\end{tabular}

Katılımcıların görüşleri doğrultusunda yapılan SWOT analizine baktığımızda güçlü yönlerin zayıf yönlerden, firsatların ise tehditlerden daha fazla olduğu görülmektedir. Ancak Çanakkale'de dalış turizminin güçlü yönleri olmasına rağmen zayıf yönler, güçlü yönleri engelleyerek Çanakkale'nin dalış turizminin gelişmesine engel olabilmektedir. Bu sorunla ilgili olarak K2'nin “Boğaz içerisinde bazı gemi geçişlerine engel olacağından dolayı su sporlarına izin verilmiyor" ve "Bu boğaz olduğu için hani gemilere engel olur, problem olur, sıkıntı yaratır diye önü kesilmiş durumda" ifadeleri bu yorumu doğrular niteliktedir. Katılımcılar, Çanakkale'deki dalıș turizminin fırsatlarını belirtirken, özellikle destinasyon tanıtımına katkı ve gelir yaratma etkisi üzerinde durmuşlardır. Ancak dalış turizminin çevre üzerindeki tehditleri de birçok katılımcı tarafından ifade edilmiş; bunun sebebi olarak da eğitimsizlik, dikkatsizlik ve kaçak yapılan dalışlara vurgu yapılmıştır. Bu konu ile ilgili K8 kodlu katılımcı, kurallara uyulursa bir sorun olmayacağını ifade ederken; K5 kodlu katılımcı, avcılığın su altı doğal yaşama, dalgıçlardan çok daha fazla zarar verdiğini belirtmiştir. Bunun yanı sıra birçok katılımcı, eğitim ve duyarlılık sağlanırsa dalış turizminin çevreye bir zararı olmayacağını ifade etmiştir.

Kültür turizminin çok yoğun gerçekleştirildiği Çanakkale'de dalış turizmi ilk tercih edilen aktivitelerden biri olarak görülmemektedir. Özellikle Şehitlik ve Troya gezileri tercih edilmekte ve insanlar Çanakkale'ye bu yerleri görme amacıyla gelmektedir. Çanakkale'de dalış turizminin gelişiminin önünde birçok engel vardır. Katılımcılar; akıntı, derinlik, gemi geçişleri gibi engellerin bulunduğunu ve yasal düzenlemelerden dolayı dalış yapılamadığını ifade etmişlerdir. Bununla birlikte bilinçsiz dalgıçların ve kaçak dalışların su altı doğal yaşama çok büyük zararları olduğu belirtilmektedir. Katılımcılara göre dalış turizminin bölgeye birçok olumlu etkisi vardır. Bölgenin tanıtımı, gelir getirmesi özellikle vurgulanan olumlu etkilerdir. Bununla birlikte su altı heykel müzeleri ve arkeoparklar ile ilgili genel tutumun olumlu olduğu görülmektedir. Bölgenin tanıtımına katkı sağlayacağı ve su altı doğal yaşamı zenginleştireceği için yapılması gerektiği ifade edilmiştir.

Sonuç olarak, Çanakkale'nin dalış turizmi potansiyelinin çok yüksek olduğu ancak ciddi bazı engellerden dolayı gelişemediği söylenebilir. Bu doğrultuda dalış için fazla derinlikte olan batıkların bir benzeri yapılabilir. Özellikle insanların merak ettiği batıkların, su altı doğal yaşama zarar vermeyecek malzeme ile benzerleri yapıldıktan sonra bu heykeller batırılarak sergilenebilir. Bu şekilde hem su altı doğal yaşamın canlanması hem de Çanakkale'de dalış turizminin gelişimi sağlanabilir. Çanakkale'nin sadece kültür turizmi destinasyonu olduğu konusundaki genel alg1, dalış turizmi ile ilgili tanıtımlara ağırlık verilerek değiştirilebilir. Kaçak dalışlar ve duyarsız dalgıçlar sebebiyle su altı doğal yaşamın olumsuz etkilenmemesi için yeni düzenlemeler yapılabilir.

Hem yabancı hem de yerli literatürde, dalış turizminin su altı doğal yaşama etkisi, sürdürülebilir dalış turizmi, yapay resifler en çok çalışılan konular arasında bulunmaktadır. Çalışmaların büyük çoğunluğu sadece dalış turizmi ve sürdürülebilirlik üzerine odaklanmaktadır. Turistlerin, dalış okullarının ve diğer paydaşların düşüncelerinin araştırıldığı çalışmalar çok az bulunmaktadır. Turistlerin motivasyonları, deneyimleri ve beklentileri araştırılarak dalış turizmine olan talep arttırılabilir. Dalış turizmini tercih eden turistlerin özellikleri belirlenebilir. Bu sayede dalış turizmini tercih eden turiste özel ve o turiste hitap eden tanıtımlar ve kampanyalar düzenlenerek turistin ilgisi destinasyona çekilebilir. 


\section{Kaynakça}

Akgündüz Y., \& Kızılcalığlu G. (2016). Likya Yolu'nu yürüyen turistlerin seyahat motivasyonları ve memnuniyet düzeyleri. Yönetim ve Ekonomi, 23(3), 817-836.

Akkoç, İbrahim T. (2015). Tüplü dalış turizmine katılan turistlerin güdüleri ve ilgilenimleri: Türkiye üzerine bir araştırma (Yüksek lisans tezi). Yükseköğretim Kurulu Ulusal Tez Merkezi'nden edinilmiştir. (Tez No. 394325).

Albayrak, A. (2013). Alternatif turizm. Ankara: Detay Yayıncılık.

Babazade, Ü. (2017). Sualtı dalış turizmi paydaşları ile İzmir su altı dalış turizmine yönelik bir swot analizi (Yüksek lisans tezi). Yükseköğretim Kurulu Ulusal Tez Merkezi'nden edinilmiştir. (Tez No. 483938).

Benitez-Cabrera, V., Becerra-Bolaños, A., \& Jorge-Millares, M. (2011). Underwater virtual maritime museum in Canary islands: website and reality proposals. $4^{\text {th }}$ International Congress on Underwater Archaeology.

Bozic, S., \& Berić, D. (2013). Tourist valorization of cultural route "the trail of the roman emperors". European Researcher, 55(7-2), 1902-1913.

Çakıcı, C., Mercan, Ş. O. \& Harman, S. (2006). Sayılarla Çanakkale turizminin değerlendirilmesi. Girişimcilik ve Kalkınma Dergisi, 1(2), 113-135.

Erçolak, G., Tanrısever, C., \& Pamukçu, H. (2019). İnanç turizmi kapsamında Aziz Paulus'un önemi ve Tarsus turizmine etkisi. B. C. Çetinsöz (Ed.), VIII. Ulusal IV. Uluslararası Doğu Akdeniz Turizm Sempozyumu içinde (s. 521-532). Mersin: Mersin Üniversitesi.

Erkurt, O. \& Paker, S. (2014). Su altı arkeoparkları ve deniz turizmi. Denizcilik Fakültesi Dergisi, 6(7). 131-144.

Genç, K., Atay, L., \& Eryaman, M. Y. (2014). Sürdürülebilir destinasyon yaratma sürecinde örgütlenmenin önemi: Çanakkale turizmi üzerine bir araştırma. Anatolia: Turizm Araştırmaları Dergisi, 25(1), 49-61.

Hammerton, Z. (2017). Determining the variables that influence scuba diving impacts in eastern Australian marine parks. Ocean \& Coastal Management, 142, 209217.

Hasler, H., \& Ott, J. A. (2008). Diving down the reefs? Intensive diving tourism threatens the reefs of the Northern red sea. Marine Pollution Bulletin, 56(10), 1788-1794.

Hawkins J. P., Callum M. R., Kooistra, D., Buchan K., \& White S. (2005) Sustainability of scuba diving tourism on coral reefs of saba. Coastal Management, 33(4), 373387.

Jeffery, B. (2004). World War II underwater cultural heritage sites in Truk lagoon: Considering a case for world heritage listing. International Journal of Nautical Archaeology, 33(1), 106-121.

Kelkit, A. (2003). Çanakkale ilinin turizm potansiyeli ve çeşitlendirilmesi. Selcuk Journal of Agriculture and Food Sciences, 17(31), 18-23.
Kirkbride-Smith, A. E., Wheeler, P. M., \& Johnson, M. L. (2013). The relationship between diver experience levels and perceptions of attractiveness of artificial reefsexamination of a potential management tool. PloSOne, $8(7), 1-11$.

Köseler, S., Koçhan, B., Atsız, N., \& Sünnetçioğlu, S. (2019). Çanakkale'de alternatif gastronomi rotaları belirlemeye yönelik bir araştırma. Türk Turizm Araştırmaları Dergisi, 3(4), 1533-1551.

Lucrezi, S., Saayman, M., \& Merwe, V. D. P. (2013). Managing diving impacts on reef ecosystems: analysis of putative influences of motivations, marine life preferences and experience on divers' environmental perceptions.

Ocean \& Coastal Management, 76, 52-63.

Naidoo, P., Munhurrun, N. P., \& Sahebdeen, Y. (2016). Customer satisfaction with scuba diving in mauritius. Proceedings of the International Academic Research Conference on Marketing \& Tourism. MTC16Paris Conference, Paris, France. 1-3 July, 2016.

Özalp, B. H. (2004). Çanakkale Savaşlarına su altından bir bakış. Çanakkale Araştırmaları Türk Yıllı̆̆ 1 95'inci Yıl Özel Sayısı, 91-110.

Özbek, M. (2014). Turizm amaçlı su altı ve su üstü sportif faaliyetler: Bugünü geleceği. Dokuz Eylül Üniversitesi Denizcilik Fakültesi Dergisi, 6(2), 27-48.

Perez-Alvaro, E. (2016). Climate change and underwater cultural heritage: Impacts and challenges. Journal of Cultural Heritage, 21, 842-848.

Prior, M., Ormond, R., Hitchen, R., \& Wormald, C. (1995). The impact on natural resources of activity tourism: a case study of diving in Egypt. International Journal of Environmental Studies, 48(3-4), 201-209.

Scalkos, G., Strigas, A., Moudakis, C., \& Stergioulas, A. (2009). Mapping of the current state of diving tourism in Greece. Journal of Applied Sciences, 9(21), 3829-3835.

Sevinç, F., \& Özel, Ç. H. (2018). Boş zaman aktivitesi olarak dalış ve yaşam doyumu ile ilişkisi. Dokuz Eylül Üniversitesi Sosyal Bilimler Enstitüsü Dergisi, 20(3), 397-415.

Staniforth, M., Hunter, J., \& Jateff, E. (2009). International approaches to underwater cultural heritage. J. W. Harris (Ed.), Maritime law issues, challenges and implications içinde (ss. 1-25). United States of America: Nova Science Publishers.

Stolk, P., Markwell, K., \& Jenkins, J. M. (2007). Artificial reefs as recreational scuba diving resources: A critical review of research. Journal of Sustainable Tourism, 15(4), 331-350.

Tavşancıl, E. \& Aslan, E (2001). İçerik analiz ve uygulama örnekleri. İstanbul: Epsilon.

Wilks, J. \& Davis, R. J. (2000). Risk management for scuba diving operators on Australia's great barrier reef. Tourism Management, 21(6), 591-599.

Yarmacı, N., Keleş, M. Ç., \& Ergil, B. (2017). Su altı dalış turizminin mevcut durumu, sorunları ve geliştirilmesine 
yönelik öneriler: Kaş örneği. Güncel Turizm Araştırmaları Dergisi, 1(1), 66-87.

Yıldırım, A., \& Şimşek, H. (2011). Sosyal bilimlerde araştırma yöntemleri. Ankara: Seçkin Yayınları.

Yıldırım, A., \& Şimşek, H. (2016). Sosyal bilimlerde araştırma yöntemleri (onuncu baskı). Ankara: Seçkin Yayınları.

Yaşar, O. (2011). Saroz Körfezi kıyılarında su altı dalış turizmi. Zeitschrift für die Welt der Türken/Journal of
World of Turks ZFWT, 3(1), 33-55.

\section{Internet kaynakları}

https://bodrum.bel.tr/sualti-arkeoloji-muzesi.html, Tarihi:07.05.2019

www.cnnturk.com/yasam/bu-su-alti-muzesi-

turkiyede?page $=1$, Erişim Tarihi: 15.04 .2019

www.yigm.kulturturizm.gov.tr, Erişim Tarihi:14.04.2019 


\section{Extended Abstract}

Preferred diving destinations in Turkey; it is indicated as Ayvalık (Balıkesir), Datça, Bodrum (Muğla), Kemer (Antalya). Çanakkale is also among these important destinations. Especially, ancient ruins and underwater features found in Eceabat, Gökçeada and Bozcaada make Çanakkale an important diving tourism destination (Babazade, 2017: 28; yigm.kulturturizm.gov.tr)

Diving tourism is one of the alternative tourism types and it is also carried out in Çanakkale. It is aimed in this study to evaluate the diving tourism potential in Çanakkale and to increase the awareness about diving tourism. In this regard, interviews were held with the stakeholders of Çanakkale tourism. In line with the findings obtained as a result of the interviews, the diving tourism of Çanakkale was evaluated by SWOT analysis.

Interviews were conducted with diving tourism stakeholders for the purpose of the study. Within the scope of this study, semi-structured interviews were conducted with 11 people. The interviews with the participants lasted between 12-30 minutes. The interviews were held face-to-face in MayAugust 2019. Descriptive analysis and content analysis were applied to the data obtained in the study. The steps to be taken to ensure validity and reliability (Yıldırım \& Şimşek, 2016: 227) were implemented in the study as follows;

- Purposeful sampling has been carried.

- Interviews with the participants were tried to be kept as long as possible.

-Direct quotations were made from the interviews with the participants.

- Method diversification (document analysis, interview) and participant diversity were tried to be provided.

- Codings were made with different researchers and compared.

Captain Franko, Kapukinka, Tavşanadası-Bozcaada, Container-Bozcaada, Havuzlar Location, Soğanlıdere, Baykuş Creek, Asos, Güzelyalı, Lundy, Water Treatment Ship, Carthage, Majestik, Lesbos Breslau, Anzac Bay, Eceabat are considered as places where diving can be done. Touristic dives should be done at a depth of less than 30 meters (Yarmac1 et al., 2017: 67) and many wrecks are at 50 meters or deeper. This situation creates an obstacle to the examination of many shipwrecks and to evaluate the diving tourism potential in Çanakkale. However, it has been determined that current, strait traffic, depth and legal practices create obstacles for diving activities in Çanakkale.

It has been determined that the development of diving tourism in Çanakkale can have positive effects on the region. It has been determined that these positive effects will be in the direction of creating touristic demand, generating income, contributing to the promotion of Çanakkale and diversifying tourism in the region. It can be stated that diving tourism activities will have positive effects on the region, on the other hand, it can be stated that some negative effects may occur on the natural life. It is also possible to conclude that these negative effects can be prevented by trained people in scuba diving.

As a result of the analysis of the data obtained in the study, the underwater diving tourism SWOT Matrix of Çanakkale was created. Accordingly, it is possible to state that Çanakkale has strengths and weaknesses in terms of diving tourism, however, it has some opportunities and faces some threats. When we look at the SWOT analysis made in line with the opinions of the participants, it is seen that the strengths are more than the weaknesses and the opportunities are more than the threats. However, diving tourism in Çanakkale has its strengths. However, weaknesses can prevent the development of diving tourism in Çanakkale by blocking the strengths.

Table 1. Canakkale Underwater Diving Tourism SWOT Matrix

\begin{tabular}{|c|c|}
\hline Strengths & Weaknesses \\
\hline $\begin{array}{l}\text {-Wealth in terms of underwater } \\
\text { diving areas. }\end{array}$ & $\begin{array}{l}\text {-Limited areas of suitable depth } \\
\text { for diving }\end{array}$ \\
\hline -Demand for underwater diving. & -Presence of current in the sea. \\
\hline $\begin{array}{l}\text {-Underwater diving being } \\
\text { carried out. }\end{array}$ & $\begin{array}{l}\text {-Legal obstacles to diving } \\
\text { tourism. }\end{array}$ \\
\hline $\begin{array}{l}\text {-Finding diving schools and } \\
\text { providing training. }\end{array}$ & $\begin{array}{l}\text {-Ship traffic and international } \\
\text { ship crossings in the Bosphorus. }\end{array}$ \\
\hline $\begin{array}{l}\text {-Carrying out activities to } \\
\text { develop diving tourism. } \\
\text {-Finding rich underwater diving } \\
\text { tourism resources. }\end{array}$ & \\
\hline Opportunities & Threats \\
\hline $\begin{array}{l}\text {-Changes in the demand for } \\
\text { touristic products. } \\
\text {-Diversifying tourism activities } \\
\text { in the region. } \\
\text { - Revealing the income } \\
\text { generation effect. } \\
\text {-Contribution to destination } \\
\text { promotion. } \\
\text { - Create new demand. }\end{array}$ & $\begin{array}{l}\text {-Illegal fishing activities. } \\
\text {-Adverse effects that may occur } \\
\text { on the environment and natural } \\
\text { life. } \\
\text { - Uneducated dives. }\end{array}$ \\
\hline
\end{tabular}

It can be said that Çanakkale has a very high diving tourism potential but could not develop due to some serious obstacles. Accordingly, a similar type of shipwrecks that are too deep for diving can be made. These sculptures can be immersed and displayed after similar shipwrecks are made with materials that will not harm underwater natural life. In this way, both the revival of underwater natural life and the development of diving tourism in Çanakkale can be achieved. The general perception that Çanakkale is only a cultural tourism destination can be changed by focusing on promotions related to diving tourism. New arrangements can be made in order not to adversely affect the underwater natural life due to illegal diving and insensitive diver. 